\title{
AKUNTABILITAS PEMERINTAH DESA DALAM PENGELOLAAN DANA DESA DI DESA SANSARINO KECAMATAN AMPANA
}

\author{
Arfin $^{1)}$, Asna Aneta ${ }^{2)}$, Sri Yulianty Mozin ${ }^{3)}$ \\ Universitas Negeri Gorontalo $1,2,3$ \\ $\underline{\text { arfinolii97@gmail.com }}^{1)}$, asnaatiek.aneta@ung.ac.id ${ }^{2)}$, yulmozin@ung.ac.id ${ }^{3)}$
}

ABSTRAK

Tujuan penelitian ini untuk mengetahui akuntabilitas manfaat dalam pengelolaan dana desa di Desa Sansarino Kecamatan Ampana Kota. Penelitian ini menggunakan metode deskriptif kualitatif. Informan penelitian terdiri dari aparat dan masyarakat desa. Pengumpulan data menggunakan teknik dokumenter, wawancara dan observasi. Analisis data penelitian melalui pengorganisasian data, pengkodean data, horizonaliting, mendeskripsikan pernyataan, menemukan esensi dari fenomena, mengembangkan textural description dan structural description, memberikan penjelasan secara naratif, membuat laporan pengalaman setiap partisipan.

Hasil penelitian menunjukkan: Pertama, akuntabilitas manfaat dalam pengelolaan dana desa di Desa Sansarino Kecamatan Ampana Kota sebagai berikut: (a) sosialisasi program pengelolaan dana desa telah dilaksanakan, sehingga informasi program pengelolaan dana desa dapat tersampaikan kepada masyarakat desa; (b) pemahaman program pengelolaan dana desa belum mencakup keseluruhan masyarakat desa; (c) ketepatan program pengelolaan dana desa sudah tepat dengan sasaran pengelolaan dana desa yang sudah ditentukan dalam perencanaan. Namun demikian, sebagian masyarakat yang menjadi kelompok sasaran yang dialokasikan dari dana desa tidak memanfaatkan secara optimal program pemberdayaan yang ada di desa; (d) pencapaian tujuan pengelolaan dana desa terwujud melalui kesesuaian antara hasil pelaksanaan program pengelolaan dana desa dengan tujuan program yang telah ditetapkan sebelumnya; (e) program pengelolaan dana desa memberikan dampak perubahan nyata atau manfaat bagi masyarakat desa.

Kata kunci: Akuntabilitas, Pemerintah Desa, Pengelolaan Dana Desa. 


\section{Pendahuluan}

Undang-Undang Republik Indonesia Nomor 32 Tahun 2004 tentang pemerintahan daerah menyebutkan bahwa pemerintahan daerah adalah pemerintah daerah yang menyelenggarakan urusan pemerintahan menurut asas otonomi dan tugas pembantuan dengan prinsip otonomi seluas-luasnya dalam sistem dan prinsip Negara Kesatuan Republik Indonesia. Pemerintah desa merupakan strata pemerintahan daerah paling bawah yang berhubungan langsung dengan masyarakat. Berkaitan dengan hal tersebut dalam UndangUndang Republik Indonesia Nomor 6 Tahun 2014 tentang Desa menegaskan bahwa desa memiliki hak dalam mengatur dan mengurus kepentingan masyarakat setempat. Pemerintah Desa adalah Kepala Desa atau yang disebut dengan nama lain dibantu perangkat desa sebagai unsur penyelenggara Pemerintahan Desa.

Peraturan Pemerintah Republik Indonesia Nomor 72 Tahun 2005 tentang Desa mengatur bahwa dana perimbangan keuangan pusat dan daerah yang diterima oleh kabupaten/ kota yang dalam pembagiannya untuk tiap desa dibagikan secara proporsional yang disebut sebagai alokasi dana desa. Anggaran tersebut diatur dalam Peraturan Pemerintah Republik IndonesiaNomor 60 Tahun 2014 tentang Dana Desa yang menyebutkan bahwa dana desa adalah dana yang bersumber dari APBN (Anggaran Pendapatan dan Belanja Negara) yang diperuntukkan bagi desa yang ditransfer melalui APBD (Anggaran Pendapatan dan Belanja Daerah) Kabupaten/Kota dan digunakan untuk membiayai penyelenggaraan pemerintahan, pelaksanaan pembangunan, pembinaan kemasyarakatan dan pemberdayaan masyarakat.
Dalam Peraturan Menteri Desa Republik Indonesia 5 Tahun 2015 disebutkan bahwa alokasi dana desa merupakan bantuan stimulan atau dana perangsang untuk mendorong dalam membiayai program penyelenggaraan pemerintahan desa, pelaksanaan pembangunan, pembinaan kemasyarakatan, dan pemberdayaan masyarakat. Peraturan Menteri Dalam Negeri Republik Indonesia Nomor 113 Tahun 2014 tentang Pengelolaan Keuangan Desa menjelaskan pokok-pokok dalam pengelolaan keuangan desa harus didasari asas transparansi, akuntabel dan partisipatif. Dalam pengelolaan dana desa, dituntut adanya suatu aspek tata pemerintahan yang baik (good governance) dimana salah satu pilarnya adalah akuntabilitas.

Berbicara mengenai akuntabilitas, hal ini berarti adanya tanggung jawab pemerintah terhadap pelayanan publik sebagai bukti kinerja. Menurut Hanafie, dkk. (2019:39) tiga jenis akuntabilitas, yaitu akuntabilitas anggaran, akuntabilitas prosedural dan akuntabilitas manfaat. Melihat luasnya pembahasan mengenai ketiga jenis akuntabilitas tersebut, maka dalam penelitian ini fokusnya adalah akuntabilitas manfaat. Menurut Rosjidi (2001:143) akuntabilitas manfaat adalah program dan kegiatan yang dilakukan oleh pemerintah desa harus dapat menunjukkan tingkat pencapaian tujuan dan sasaran yang telah ditetapkan, serta berorientasi pada pencapaian visi, misi, hasil dan manfaat yang diperoleh. Menurut Adisasmita (2011:30), akuntabilitas manfaat berkaitan erat dengan efektivitas yang memberi perhatian kepada hasil kegiatan pemerintah dalam hal ini semua aparat pemerintah dipandang berkemampuan melakukan pencapaian tujuan dan tidak hanya patuh terhadap kebutuhan hierarki atau prosedur. 
Wujud dari pertanggungjawaban dalam akuntabilitas manfaat antara lain dengan adanya proses pengawasan pengelolaandana desa agar penggunaannya tepat sasaran (Kholmi, 2016; Rosalinda, 2014; Juliansyah (2013). Keterkaitan akuntabilitas manfaat dengan efektivitas hasil kegiatan pemerintah desa dalam pengelolaan dana desa terlihat dari indikator tercapainya manfaat hasil kegiatan program seperti dalam penelitian Budiani (2007:53) dan penelitian Dewi \& Rahaju (2018:4) yaitu: (1) sosialisasi program pengelolaan dana desa, (2) pemahaman program pengelolaan dana desa, (3) ketepatan sasaran pengelolaan dana desa, (4) pencapaian tujuan pengelolaan dana desa, dan (5) perubahan nyata atau dampak dari pengelolaan dana desa.

Desa Sansarino adalah salah satu desa di Kecamatan Ampana Kota sangat menarik bagi peneliti untuk melakukan penelitian dan kajian tentang akuntabilitas pemerintah desa dalam pengelolaan dana desa yang teranggarkan pada tiga tahun terakhir (2017-2019). Alokasi dana desa dimana anggaran dan realisasi dana desa dalam tiga tahun terakhir sebagaimana pada Tabel 1 sebagai berikut:

Tabel 1. Realisasi Pelaksanaan APBD Pemerintah Desa Sansarino Kecamatan Ampana Kota dalam Tiga Tahun Terakhir

\begin{tabular}{c|c|c}
\hline Tahun & Anggaran (Rp) & Realisasi (Rp) \\
\hline 2017 & $1.290 .250 .234,00$ & $1.294 .335 .537,00$ \\
\hline 2018 & $1.241 .696 .514,22$ & $1.244 .094 .379,00$ \\
\hline 2019 & $1.390 .660 .827,78$ & $1.392 .254 .201,00$ \\
\hline
\end{tabular}

Data pada Tabel 1 di atas menunjukkan adanya peningkatan anggaran dan realisasi pada tahun 2019 dibandingkan dengan dua tahun sebelumnya. Dengan adanya peningkatan tersebut, diharapkan penyelenggaraan pemerintahan desa dapat berjalan dengan optimal, serta mampu melaksanakan pembangunan desa sesuai dengan rencana yang ditetapkan dalam Musrenbangdes. Seiring dengan harapan ideal tersebut di atas, realitas empiris dalam penelitian awal menunjukkan bahwa akuntabilitas manfaat pengelolaan dana desa di Desa Sansarino Kecamatan Ampana Kota belum sesuai dengan harapan masyarakat.

Masalah pertama akuntabilitas pemerintah desa dalam pengelolaan dana desa di Desa Sansarino Kecamatan Ampana Kota nampak dari sosialisasi program pengelolaan dana desa yang belum optimal. Dari wawancara awal dengan para informan dalam penelitian awal pada bulan Januari 2020, diperoleh data bahwa berbagai bentuk sosialisasi selama ini masih belum optimal dalam menjembatani apa yang menjadi harapan Pemerintah Desa Sansarino Kecamatan Ampana Kota dengan masyarakat, sehingga masih ditemukan adanya perbedaan persepsi mengenai skala prioritas dalam penganggaran. Sebagai contoh, pemerintah desa cenderung berfokus pada prioritas peningkatan kesejahteraan perangkat desa dan peningkatan pembangunan fisik. Sementara hal utama bagi masyarakat adalah penyediaan modal usaha keripik maupun usaha lainnya. Selain itu, beberapa masyarakat yang tidak terlibat dan tidak diikutkan dalam Musrembangdes menilai bahwa beberapa proyek yang didanai oleh dana desa itu belum mendesak dan masih bisa ditunda.

Masalah kedua akuntabilitas pemerintah desa dalam pengelolaan dana desa di Desa Sansarino Kecamatan Ampana Kota nampak dari pemahaman program yang belum optimal. Adanya informasi tentang dana desa di papan pengumuman desa tidak menjamin adanya pemahaman yang merata kepada semua lapisan masyarakat karena 
hanya pihak yang melihat pengumuman yang lebih banyak bisa menyerap informasi. Selain itu, melalui cross check kepada beberapa masyarakat diperoleh informasi bahwa selama ini mereka belum mendapatkan informasi yang cukup dan menyeluruh mengenai pengelolaan dana desa tersebut, sehingga berdampak pada lemahnya komitmen masyarakat dalam mendukung pembangunan desa.

Masalah ketiga akuntabilitas pemerintah desa dalam pengelolaan dana desa di Desa Sansarino Kecamatan Ampana Kota nampak dari ketepatan sasaran yang belum optimal. Masih ada program pembangunan desa yang mengalami kegagalan. Salah satunya adalah program pemberdayaan masyarakat dalam pengembangan usaha petani kakao yang berusaha memberantas fenomena kemiskinan yang terjadi pada beberapa penduduk Desa Sansarino Kecamatan Ampana Kota. Dukungan pendanaan untuk petani kakao dalam mengembangkan budidaya tanaman kakao bisa dikatakan hampir tidak ada atau sangat minim, sehingga peningkatan hasil produksi tanaman kakao juga tidak sesuai harapan masyarakat.

Masalah keempat akuntabilitas pemerintah desa dalam pengelolaan dana desa di Desa Sansarino Kecamatan Ampana Kota nampak dari tujuan program yang belum optimal. Pengelolaan dana desa belum sepenuhnya diprioritaskan untuk menanggulangi kemiskinan dan mengurangi kesenjangan diantara masyarakat Desa Sansarino Kecamatan Ampana Kota. Beberapa informan dari masyarakat miskin ada yang mengakui bahwa mereka bahkan belum mendapatkan modal usaha untuk mengembangkan perekonomiannya.

Masalah kelima akuntabilitas pemerintah desa dalam pengelolaan dana desa di Desa
Sansarino Kecamatan Ampana Kota nampak dari perubahan nyata dari pengelolaan dana desa yang belum optimal. Beberapa masyarakat mengeluh bahwa manfaat dari program pengelolaan dana desa dirasakan belum sepenuhnya menyentuh kebutuhan yang urgen dan mendesak, serta belum memberi perubahan nyata dari masyarakat.Dalam arti program yang terealisasi bukan merupakan skala prioritas atau belum memiliki nilai manfaat yang tinggi dan signifikan bagi masyarakat.

Masalah-masalah akuntabilitas manfaat dalam pengelolaan dana desa di atas terhambat oleh beberapa faktor. Dalam wawancara awal dengan beberapa informan pada bulan Januari 2020 terungkap bahwa faktor partisipasi masyarakat dalam pengambilan manfaat belum optimal. Beberapa orang unsur masyarakat bahkan ada yang menolak akibat ketidaksesuaian antara infrastruktur yang dibangun dan yang menjadi kebutuhan mereka. Sebagian masyarakat yang menjadi informan menilai bahwa partisipasi mereka hampir tidak ada dalam hal melakukan evaluasi yang menyangkut urusan pelaksanaan program secara keseluruhan.

Faktor kepemimpinan kepala Desa Sansarino Kecamatan Ampana Kota juga dinilai belum mampu merangkul seluruh elemen masyarakat untuk ikut berpartisipasi dalam pembangunan desa. Sebagian masyarakat memandang kepala desa masih belum memahami berbagai aturan yang berlaku terkait dengan pengelolaan keuangan desa. Faktor pengawasan belum optimal dalam mendukung akuntabilitas pemerintah desa dalam pengelolaan dana desa di Desa Sansarino Kecamatan Ampana Kota. Menurut masyarakat, pengawasan belum dilakukan secara ketat dan berkala baik oleh pihak internal (pemerintah desa 
dan masyarakat) maupun pihak eksternal (inspektorat kabupaten). Ada anggapan dan kekhawatiran dari sebagian masyarakat bahwa jika pengawasan tidak dilakukan secara ketat dan berkala, maka bisa jadi kecurangan dalam pengelolaan dana desa di Desa Sansarino Kecamatan Ampana Kota tidak dapat diminimalisir.

\section{Kajian Teori}

\subsection{Konsep Good Governance}

Good Governance diartikan sebagai mekanisme, praktek dan tata cara pemerintahan dan warga mengatur sumber daya serta memecahkan masalah-masalah publik (Tahir, 2014:106). Dalam good governance, akuntabilitas merupakan elemen penting dan menjadi tantangan tersendiri bagi pemerintah dan aparatur sipil Negara. Dalam rangka mendukung terwujudnya good governance dalam penyelenggaraan desa, pengelolaan keuangan desa dilakukan berdasarkan prinsip tata kelola yaitu transparan, akuntabel dan partisipatif serta dilakukan dengan tertib dan disiplin anggaran.

Syarat-syarat bagi terciptanya good governance adalah adanya transparansi dalam penyelenggaraan pemerintahan, pemerintahan partisipatif bagi masyarakat, dan akuntabilitas (Waluyo, 2007:203). Akuntabilitas dapat dibagi menjadi beberapa aspek antara lain (Adisasmita, 2011:30): (1) Akuntabilitas keuangan: merupakan pertanggungjawaban mengenai integritas keuangan, pengungkapan dan ketaatan terhadap peraturan perundang-undangan; (2) Akuntabilitas manfaat: memberi perhatian kepada hasil kegiatan pemerintah dalam hal ini semua aparat pemerintah dipandang berkemampuan melakukan pencapaian tujuan dan tidak hanya patuh terhadap kebutuhan hierarki atau prosedur; (3) Akuntabilitas prosedural: merupakan pertanggungjawaban mengenai apakah suatu prosedur penetapan dan pelakasanaan kebijakan telah mempertimbangkan masalah moralitas,etika, kepastian hukum, dan ketaatan pada keputusan politis untuk mendukung pencapaian tujuan akhir yang telah ditetapkan.

\subsection{Konsep Akuntabilitas Manfaat Dalam Pengelolaan Dana Desa}

Akuntabilitas merupakan salah satu prinsip tata kelola pemerintahan yang baik atau Good Govermance. Menurut Ulum (2004) akuntabilitas adalah perwujudan kewajiban untuk mempertanggungjawabkan keberhasilan atau kegagalan atas pelaksanaan misi organisasi dalam mencapai tujuan-tujuan dan sasaran-sasaran yang telah ditetapkan melalui suatu media pertanggungjawaban secara periodik. Selanjutnya akuntabilitas manfaat adalah pertanggungjawaban yang mencakup hasil pencapaian tujuan yang sesuai dengan prosedur dan terpenting dalam pencapaian tujuan tersebut adalah efektivitas (Mohamad, dkk: 2004). Untuk mengukur efektivitas akuntabilitas manfaat dalam pengelolaan dana desa dapat dilihat dari indikator efektivitas program yaitu: (1) sosialissi program pengeloaan dana desa, (2) pemahaman program pengelolaan dana desa, (3) ketepatan sasaran pengelolaan dana desa, (4) pencapaian tujuan pengelolaan dana desa, (5) perubahan nyata pengelolaan dana desa.

\section{Metode}

Jenis penelitian ini termasuk dalam tipe penelitian deskriptif kualitatif yang berusaha mendeskripsikan gambaran yang senyatanya dari fenomena yang terjadi pada akuntabilitas pemerintah desa dalam pengelolaan dana desa di Desa Sansarino Kecamatan Ampana Kota. Oleh karena merupakan penggambaran dari sebuah 
fenomena, maka penelitian ini dianggap juga penelitian fenomonologi. Lokasi penelitian ini yaitu di Desa Sansarino Kecamatan Ampana Kota. Adapun Informan dalam penelitian ini adalah seluruh aparat desa dan unsur masyarakat yang terkait dengan fokus penelitian ini.

Pengumpulan data dalam penelitian ini adalah (1) Teknik dokumenter digunakan untuk mengumpulkan data yang bersumber dari buku teks yang menyajikan teori, dokumen (peraturan perundangan dan peraturan lainnya), naskah tertulis berupa persuratan/ laporan, serta gambar/ foto yang berkaitan dengan fokus penelitian; (2) Teknik wawancara sistematik dimana wawancara dilakukan dengan terlebih dahulu pewawancara mempersiapkan pedoman (quide) tertulis tentang apa yang hendak ditanyakan kepada informan; (3) Teknik observasi digunakan untuk mengamati berbagai aspek yang berkenaan dengan fokus penelitian yang digunakan untuk memperkuat dan melengkapi hasil wawancara. Dalam penelitian ini, peneliti berperan penuh sebagai observer.

Teknik analisis data yaitu (1) Peneliti memulai mengorganisasikan semua data atau gambaran menyeluruh tentang fenomena pengalaman yang telah dikumpulkan; (2) Membaca data secara keseluruhan dan membuat catatan pinggir mengenai data yang dianggap penting kemudian melakukan pengkodean data; (3) Menemukan dan mengelompokkan makna pernyataan yang dirasakan oleh responden dengan melakukan horizonaliting yaitu setiap pernyataan pada awalnya diperlakukan memiliki nilai yang sama; (4) Selanjutnya, pernyataan yang tidak relevan dengan topik dan pertanyaan maupun pernyataan yang bersifat repetitif atau tumpang tindih dihilangkan, sehingga yang tersisa hanya horizons (arti tekstural dan unsur pembentuk atau penyusun dari fenomena yang tidak mengalami penyimpangan); (5) Pernyataan tersebut kemudian di kumpulkan ke dalam unit makna lalu ditulis gambaran tentang bagaimana pengalaman tersebut terjadi; (6) Selanjutnya peneliti mengembangkan uraian secara keseluruhan dari fenomena tersebut sehingga menemukan esensi dari fenomena tersebut; (7) Kemudian mengembangkan textural description (mengenai fenomena yang terjadi pada responden) dan structural description (yang menjelaskan bagaimana fenomena itu terjadi); (8) Peneliti kemudian memberikan penjelasan secara naratif mengenai esensi dari fenomena yang diteliti dan mendapatkan makna pengalaman responden mengenai fenomena tersebut; (9) Membuat laporan pengalaman setiap partisipan.

\section{Hasil Penelitian dan Pembahasan}

Akuntabilitas manfaat berkenaan dengan program dan kegiatan yang dilakukan oleh pemerintah desa harus dapat menunjukkan tingkat pencapaian tujuan dan sasaran yang telah ditetapkan. Hal ini terkait erat dengan efektivitas yang pada dasarnya memberi perhatian kepada hasil kegiatan pemerintah desa dilihat dari aspek (1) sosialisasi program pengelolaan dana desa, (2) pemahaman program pengelolaan dana desa, (3) ketepatan sasaran pengelolaan dana desa, (4) pencapaian tujuan pengelolaan dana desa, dan (5) perubahan nyata atau dampak dari pengelolaan dana desa.

\subsection{Sosialisasi program pengelolaan dana desa}

Sosialisasi program pengelolaan dana desa menggambarkan kemampuan pemerintah Desa Sansarino Kecamatan Ampana Kota dalam melakukan sosialisasi program pengelolaan dana desa, sehingga informasi mengenai pelaksanaan 
program pengelolaan dana desa dapat tersampaikan kepada masyarakat Desa Sansarino Kecamatan Ampana Kota.

Dalam Peraturan Bupati Tojo Una-Una Nomor 9 Tahun 2017, proses sosialisasi pengelolaan dana desa sebagai berikut:

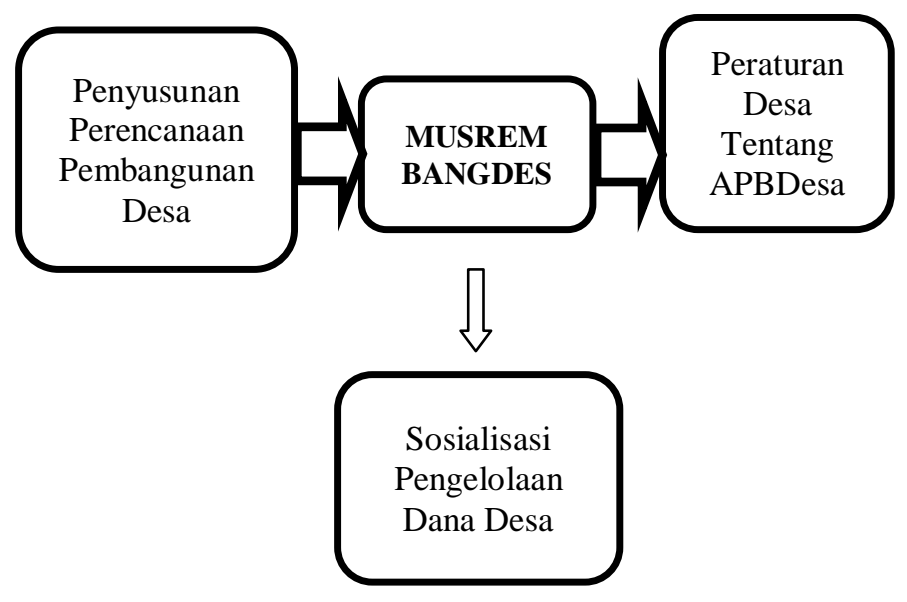

\section{Gambar 1. Proses Sosialisasi Program}

\section{Pengelolaan Dana Desa}

Berdasarkan penelitian diketahui bahwa dalam sosialisasi program pengelolaan dana desa, Pemerintah Desa Sansarino Kecamatan Ampana Kota telah mampu melakukan sosialisasi program pengelolaan dana desa, sehingga informasi mengenai pelaksanaan program pengelolaan dana desa dapat tersampaikan kepada masyarakat Desa Sansarino Kecamatan Ampana Kota. Keterkaitan antara hasil penelitian Atmadi \&Widati (2015) dengan hasil penelitian ini, maka sosialisasi berarti proses dimana masyarakat Desa Sansarino Kecamatan Ampana Kota dididik untuk mengenal dan memahami serta mempelajari peranan mereka dalam program pengelolaan dana desa. Sedangkan keterkaitan antara hasil penelitian Pertiwi \& Nurcahyanto (2017) dengan hasil penelitian ini menunjukkan sosialisasi program pengelolaan dana desa merupakan langkah awal yang menetukan keberhasilan program dalam mencapai tujuan, oleh karena itu, sosialisasi program pengelolaan dana desa harus dilakukan agar semua informasi tersampaikan dan dapat dipahami oleh seluruh masyarakat Desa Sansarino Kecamatan Ampana Kotaagar tujuan yang direncanakan bisa tercapai dengan baik.

\section{Pemahaman Program Pengelolaan Dana Desa}

Pemahaman program pengelolaan dana desa di Desa Sansarino Kecamatan Ampana Kota pada dasarnya adalah pemahaman masyarakat terhadap dana desa itu sendiri. Pemerintah desa sejak tahun 2017 dalam merealisasi alokasi dana desa melebihi target, hal ini menumbuhkan kesadaran bagi masyarakat desa bahwa mereka adalah pihak yang berkepentingan (stakeholder) dalam pengelolaan dana desa. Namun, pemahaman masyarakat di desa Sansarino Kecamatan Ampana Kota sebagai perencana, pelaksana dan pengevaluasi program ini masih kurang, sehingga menyebabkan masyarakat cenderung kurang berpartisipasi dalam program pengelolaandana desa. Walaupun sudah ada masyarakat yang ikut berperan aktif dalam pengelolaan alokasi dana desa terutama mereka yang terlibat dalam Musrembang, namun hasilnya tidaklah signifikan, karena jumlah masyarakat yang sudah berpartisipasi jauh lebih sedikit dibandingkan masyarakat yang belum berpartisipasi.

Mayoritas masyarakat desa adalah lulusan SD bahkan ada yang sama sekali tidak sekolah mengakibatkan adanya kecendrungan pemahaman tentang pengelolaan dana desa yang sulit untuk ditumbuhkan dalam pemikiran masyarakat, sehingga masyarakat juga kurang memahami tujuan dari pengelolaan dana desa dan kewajiban mereka sebagai pengelola langsung dari pengelolaan dana desa tersebut. Berdasarkan penelitian diketahui bahwa dalam pemahaman program pengelolaan dana desa, mayoritas masyarakat Desa Sansarino 
Kecamatan Ampana Kota belum memahami berbagai kegiatan dalam pengelolaan dana desa dan kewajiban mereka sebagai pengelola langsung dari pengelolaan dana desa tersebut.

Keterkaitan antara hasil penelitian Pertiwi \& Nurcahyanto (2017) dengan hasil penelitian ini, bahwa untuk mencapai pemahaman program pengelolaan dana desa tentunya harus ada konsep dalam pelaksanaan program tersebut karena program merupakan salah satu upaya untuk mencapai tujuan. Oleh karena itu, dalam pelaksanaan program pengelolaan dana desa Desa Sansarino Kecamatan Ampana Kotadiperlukan prosedur kerja yang jelas agar program kerja dapat dilaksanakan dan berjalan sesuai dengan yang diharapkan. Sedangkan keterkaitan antara hasil penelitian Jannah \& Niswah (2016) dengan hasil penelitian ini, maka dengan adanya masyarakat yang belum memahami program pengelolaan dana desa akan lebih sulit mengorganisir dan mengoperasionalkan bentuk program tersebut. Dengan minimnya pengetahuan dan pemahaman, maka pemerintah desa dan masyarakat tidak memahami kedudukan dan perannya masingmasing yang diharapkan dapat secara optimal terlibat dan berkontribusi dalam pengelolaan dana desa.

\section{Ketepatan Sasaran Pengelolaan Dana Desa}

Walaupun ketepatan hasil yang dicapai secara nyata oleh pemerintah desa dalam pengelolaan dana desa tahun anggaran 2019 sesuai yang ditargetkan dalam Rencana Pendapatan dan Belanja Desa Sansarino Kecamatan Ampana Kota, namun dalam hal tingkat partisipasi masyarakat dan pemberdayaan masyarakat desa itu sendiri belum sesuai dengan harapan. Dapat diamati bahwa beberapa masyarakat yang menjadi kelompok target sasaran dalam pemberdayaan masyarakat desa tidak memanfaatkan secara optimal program pemberdayaan ini. Sebagian masyarakat yang menjadi sasaran cenderung tidak serius mengikuti berbagai pelatihan yang diselenggarakan oleh pemerintah desa.

Berdasarkan penelitian diketahui bahwa dalam program pengelolaan dana desa di Desa Sansarino Kecamatan Ampana Kota tepat dengan sasaran pengelolaan dana desa yang sudah ditentukan dalam Rencana Pelaksanaan Anggaran Pendapatan dan Belanja desa. Namun demikian, sebagian masyarakat yang menjadi kelompok sasaran yang dialokasikan dari dana desa tidak memanfaatkan secara optimal program pemberdayaan di Desa Sansarino Kecamatan Ampana Kota.

Keterkaitan hasil penelitian Jannah \& Niswah (2016) dengan hasil penelitian ini, dilihat dari adanya bagaimana kesesuaian programprogram yang dirancang oleh Pemerintah Desa Sansarino Kecamatan Ampana Kota kepada kelompok sasaran dalam hal ini masyarakat. Dari sini dapat dinilai Pemerintah Desa Sansarino Kecamatan Ampana Kotaberhasil merealisasikan sasaran yang hendak dicapai. Sedangkan keterkaitan hasil penelitian Jibril (2017) dengan hasil penelitian ini, maka ketepatan sasaran Pemerintah Desa Sansarino Kecamatan Ampana Kotadalam pengelolaan dana desa berhubungan dengan penentuan siapa saja sasaran program pengelolaan dana desa yang dalam hal ini adalah kelompok sasaran program pengelolaan dana desa.

\section{Pencapaian Tujuan Pengelolaan Dana Desa}

Salah satu pencapaian tujuan dalam pengelolaan dana desa di Desa Sansarino 
Kecamatan Ampana Kota adalah menurunkan angka kemiskinan masyarakat desa. Melihat jumlah masyarakat desa yang miskin mengalami fenoma yang menurun, dimana dengan adanya pengelolaan dana desa, makajumlah masyarakat yang miskin menjadi kurang sebagai berikut:

\section{Tabel 1. Angka Kemiskinan Berdasarkan Kepala Keluarga di Desa Sansarino Tahun 2019}

\begin{tabular}{|c|c|}
\hline Tahun & Jumlah \\
\hline 2017 & $450 \mathrm{KK}$ \\
\hline 2018 & $320 \mathrm{KK}$ \\
\hline 2019 & $150 \mathrm{KK}$ \\
\hline
\end{tabular}

Berdasarkan penelitian diketahui bahwa dalam pencapaian tujuan pengelolaan dana desa, Pemerintah Desa Sansarino Kecamatan Ampana Kotadapat mewujudkan kesesuaian antara hasil pelaksanaan program pengelolaan dana desa di Desa Sansarino Kecamatan Ampana Kota dengan tujuan program yang telah ditetapkan sebelumnya. Pencapaian tujuan pengelolaan dana desa sudah selaras dengan apa yang menjadi visi, misi dan tujuan pemerintah desa, serta telah berhasil dalam menurunkan angka kemiskinan masyarakat desa. Keterkaitan hasil penelitian Jannah \& Niswah (2016) dengan penelitian ini bahwa pengelolaan dana desa di Desa Sansarino Kecamatan Ampana Kota dapat dikatakan bermanfaat karena dapat mencapai tujuan yang telah ditentukan sebelumnya. Keterkaitan hasil penelitian ini dengan arahan Kemenkeu RI (2017) dan teori Soemantri (2011) bahwa tujuan pengelolaan dana desa adalah menurunkan tingkat kemiskinan masyarakat desa. Dalam hal ini Pemerintah Desa Sansarino Kecamatan Ampana Kota harus terus memprioritaskan pengelolaan dana desa untuk menurunkan angka kemiskinan, menurunkan pengangguran, dan meningkatkan kesejahteraan masyarakat.

\section{Perubahan Nyata Pengelolaan Dana Desa.}

Pengelolaan dana desa merupakan bagian penting yang tidak dipisahkan dari pengelolaan keuangan desa dalam APBDes. Seluruh kegiatan harus dapat dipertanggung jawabkan secara administratif, teknis dan hukum. Intinya pengelolaan dana desa bertujuan mempercepat pembangunan desa dengan alokasi dana yang dikelola langsung oleh masyarakat. Dengan adanya program tersebut pemerintah desa diharapkan mampu dan bisa melaksanakan semua tugas-tugas umum penyelenggaraan pemerintahan Desa terkhusus pada pengelolaan dana desa. Semua perangkat desa dituntut untuk lebih profesional dalam tugas yang diberikan, sehingga para perangkat desa mampu mengelola dana desa dengan baik dan dapat memberikan dampak positif bagi masyarakat terkhusus pada program pembangunan dan pemberdayaan masyarakat.

Bagi masyarakat, dampak perubahan yang diharapkan dari pengelolaan dana desa pada umumnya adalah untuk menciptakan perubahan dalam kehidupan masyarakat. Dapat diamati bahwa dampak dari pengelolaan dana desa di Desa Sansarino Kecamatan Ampana Kota adalah:

1. Melalui pengelolaan dana desa, Pemerintah Desa Sansarino Kecamatan Ampana Kota dapat meningkatkan kesejahteraan masyarakat dan dapat mengembangkan BUMDes. Terwujudnya peningkatan tersebut karena diikuti oleh meningkatnya konsolidasi internal di desa antara masyarakat, kepala desa dan Badan Permusyawaratan Desa (BPD). Dalam hal ini walaupun kepala desa menjadi penguasa desa, namun dalam mengelola dan menggunakan 
dana Desa bukan hanya otoritas dari kepala desa juga melibatkan unsure-unsur masyarakat dan BPD, mulai dari menyusun hingga mengawasi program.

2. Melalui pengelolaan dana desa, Pemerintah Desa Sansarino Kecamatan Ampana Kota dapat meningkatkan infrastruktur desa dan peringkat Indeks Pembangunan Manusia (IPM). IPM Desa Sansarino Kecamatan Ampana Kotatahun 2020 berada pada peringkat I untuk lingkup kecamatan Ampana Kota. IPM tersebut menjelaskan bagaimana penduduk Desa Sansarino Kecamatan Ampana Kotadapat mengakses hasil pembangunan dalam memperoleh pendapatan, kesehatan, pendidikan, dan sebagainya. IPM dibentuk atas tiga dimensi dasar, yaitu; umur panjang dan hidup sehat; pengetahuan; dan standard hidup layak. Artinya bahwa pemanfaatan yang sebesar-besarnya dari danaDesa Sansarino Kecamatan Ampana Kotauntuk kepentingan masyarakat bukan hanya pembangunan fisik tetapi juga pembangunan non-fisik yaitu peningkatan kualitas manusia.

3. Melalui pengelolaan dana desa, Pemerintah Desa Sansarino Kecamatan Ampana Kota dapat mendorong pertumbuhan pembangunan daerah dan sinkronnya pembangunan desa berdasarkan Rencana Tata Ruang dan Wilayah (RTRW) Kabupaten Tojo Una-Una. Jumlah danadesa yang meningkat dalam tiga tahun terakhir dapat mendorong percepatan pembangunan desa. Dana desa yang dikelola oleh Pemerintah Desa Sansarino Kecamatan Ampana Kotamenjadi sugesti mendorong pertumbuhan pembangunan daerah yang pemanfaatannya sinkron dengan kebijakan pembangunan Daerah. Selanjutnya
Dampak nyata yang diamati dari pengelolaan dana desa di Desa Sansarino Kecamatan Ampana Kotabagi masyarakat dan pembangunan, diantaranya:

1. Sarana prasarana desa seperti jalan desa, penyulingan air dan irigasi lebih baik, sehingga meningkatkan kesejahteraan masyarakat terutama petani yang merupakan mata pencaharian dari 80 persen kepala keluarga.

2. Kegiatan ekonomi masyarakat desa semakin giat, ditandai dengan tumbuh dan berkembangnya Badan Usaha Milik Desa (BUMDes).

Berdasarkan penelitian diketahui bahwa program pengelolaan dana desa memberikan dampak perubahan nyata atau manfaat bagi masyarakat Desa Sansarino Kecamatan Ampana Kota yaitu terwujudnya peningkatan kesejahteraan masyarakat dan pengembangan BUMDes, meningkatnya infrastruktur desa dan peringkat Indeks Pembangunan Manusia (IPM), mendorong pertumbuhan pembangunan daerah dan sinkronnya pembangunan desa berdasarkan Rencana Tata Ruang dan Wilayah (RTRW) Kabupaten Tojo UnaUna.

Keterkaitan penelitian ini dengan hasil penelitian Makalalag, dkk (2016), maka program PemerintahDesa Sansarino Kecamatan Ampana Kota melalui pengelolaan dana desa sudah memberikan perubahan nyata untuk memperbaiki kondisi dan taraf hidup masyarakat dalam rangka pembangunan nasional demi tercapainya kesejahteraan adil dan merata. Perubahan nyata berkaitan erat dengan dampak dan manfaat dari pengelolaan dana desa. Keterkaitan penelitian ini dengan hasil penelitian Kusmana \& Ismail (2018) menunjukkan masyarakat Desa Sansarino 
Kecamatan Ampana Kota percaya bahwa dengan adanya pengelolaan dana desa yang ditawarkan mereka akan merasakan manfaat yang didapat dari pengelolaan dana desa tersebut. Masyarakat Desa Sansarino Kecamatan Ampana Kota telah dapat merasakan manfaat langsung maupun tidak langsung yang diterima sebagai akibat adanya pengelolaan dana desa, seperti pemanfaatan jalan desa, gedung pertemuan, dan sarana fisik lainnya. Pengelolaan dana desa serta manfaat keberadaan dana desa bagi pembangunan di Desa Sansarino Kecamatan Ampana Kotaharus dilaksanakan sesuai dengan peraturan perundang-undangan yang berlaku, sehingga akuntabilitas dapat diwujudkan.

\section{Penutup}

\subsection{Kesimpulan}

Kinerja Akuntabilitas manfaat dalam pengelolaan dana desa di Desa Sansarino Kecamatan Ampana Kota terwujud melalui (1) kemampuan Pemerintah Desa dalam melakukan sosialisasi program pengelolaan dana desa, (2) ketepatan sasaran pengelolaan dana desa sesuai Rencana Pelaksanaan Anggaran Pendapatan dan Belanja Desa, (3) memberikan dampak perubahan nyata atau manfaat bagi masyarakat melalui peningkatan kesejahteraan masyarakat dan pengembangan BUMDes, peningkatan infrastruktur desa dan peringkat Indeks Pembangunan Manusia (IPM), mendorong pertumbuhan pembangunan daerah dan sinkronnya pembangunan desa berdasarkan Rencana Tata Ruang dan Wilayah (RTRW) Kabupaten Tojo Una-Una. Namun demikian, mayoritas masyarakat belum memahami berbagai kegiatan dalam pengelolaan dana desa dan kewajiban mereka sebagai pengelola langsung dari pengelolaan dana desa tersebut. Sebagian masyarakat yang menjadi kelompok sasaran yang dialokasikan dari dana desa tidak memanfaatkan secara optimal program pemberdayaan di Desa Sansarino Kecamatan Ampana Kota.

\subsection{Saran}

Memperhatikan mayoritas masyarakat belum memahami berbagai kegiatan dalam pengelolaan dana desa dan kewajiban mereka sebagai pengelola langsung dari pengelolaan dana desa tersebut dan sebagian masyarakat yang menjadi kelompok sasaran yang dialokasikan dari dana desa tidak memanfaatkan secara optimal program pemberdayaan di Desa Sansarino Kecamatan Ampana Kota, maka Pemerintah Desa Sansarino Kecamatan Ampana Kota perlu menggalakkan kegiatan sosialisasi pengelolaan dana desa secara intensif dalam berbagai kegiatan baik formal maupun non formal.

\section{REFERENSI}

Adisasmita, R. (2011). Manajemen Pemerintah Daerah. Pusat Pengembangan Keuangan dan Ekonomi Daerah. Makassar: Universitas Hasanuddin.

Akadun. (2009). Teknologi Informasi Administrasi. Bandung: Alfabeta.

Atmadi, G., \& Widati, S. R. W. (2015). Strategi Pemilihan Media Komunikasi LPPOM MUI Dalam Sosialisasi \& Promosi Produk Halal di Indonesia. Jurnal Al-Azhar Indonesia Seri Pranata Sosial, 2(2), 87-97.

Budiani, N.W. (2007). Efektivitas Program Penanggulangan Pengangguran Karang Taruna "Eka Taruna Bhakti" Desa Sumerta Kelod Kecamatan Denpasar Timur Kota Denpasar. Jurnal Ekonomi dan Sosial Vol. 2(1), 49-57.

Dewi, N. K. A. J. P., \& Gayatri, G. (2019). FaktorFaktor Yang Berpengaruh Pada Akuntabilitas Pengelolaan Dana Desa. EJurnal Akuntansi, 1269-1298. 
Dewi, N. M. P, \& Rahaju, T. (2018). Efektivitas Pengelolaan Dana Alokasi Khusus (DAK) Bidang Pendidikan Di Desa Sumberagung Kecamatan Dander Kabupaten Bojonegoro. Publika, 6(6), 1-7.

Hanafie, H., Nugraha, A., \& Huda, M. (2019). Akuntabilitas Dana Desa (Kajian Tentang Akuntabilitas Dana Desa Di Kecamatan Masalembu, Kabupaten Sumenep). JIP (Jurnal Ilmu Pemerintahan): Kajian Ilmu Pemerintahan dan Politik Daerah, 4(1), 3946.

Jannah, S. F., \& Niswah, F. (2016). Efektivitas Program Siaran Radio Suara Pendidikan Dalam Meningkatkan Kualitas Pendidikan (Studi Di Dinas Pendidikan Kabupaten Jombang). Jurnal Publika 4(3), 1-8.

Jibril, A. (2017). Efektivitas program perpuseru di perpustakaan umum Kabupaten Pamekasan. Jurnal Universitas Airlangga, 6(2), 1-8.

Juliansyah, D. 2013. Studi Tentang Pengelolaan Alokasi Dana Desa di Desa Salimbatu Kec. Tanjung Palas Tengah, Kabupaten Bulungan. E-Journal Ilmu Pemerintahan. 1(2), 822-834.

Kholmi, M. (2016). Akuntabilitas Pengelolaan Alokasi Dana Desa: Studi di Desa Kedungbetik Kecamatan Kesamben Kabupaten Jombang. Ekonomika-Bisnis 7(2), 143-152.

Kusmana, D., \& Ismail, I. (2018). Manfaat Alokasi Dana Desa Bagi Pembangunan Dan Masyarakat Desa. Jurnal Otonomi \& Keuangan Daerah, 81-100.

Makalalag, A. J., Nangoi, G. B., \& Karamoy, H. (2017). Akuntabilitas pengelolaan dana desa di kecamatan Kotamobagu Selatan kota Kotamobagu. Jurnal Riset Akuntansi Dan Auditing" Goodwill", 8(1).

Peraturan Menteri Dalam Negeri Republik Indonesia Nomor 113 Tahun 2014 tentang Pengelolaan Keuangan Desa.

Siagian, S.P. (2015). Manajemen Sumber Daya Manusia. Jakarta: Bumi Aksara.

Soemantri, B.T. (2011). Pedoman Penyelenggaraan Pemerintah Desa. Bandung: Fokusmedia.
Tahir, A. (2014). Kebijakan publik dan transparansi penyelenggaraan pemerintahan daerah. Penerbit Alfabeta.

Undang-Undang Republik Indonesia Nomor 32 Tahun 2004 tentang Pemerintahan Daerah.

Waluyo, A. (2007). Manajemen Publik. Konsep, Aplikasi \& Implementasinya Dalam Pelaksanaan Otonomi Daerah. Bandung: Mandar Maju. 